\title{
Comedy Films of Malaysian Studio Era: A Social Culture Criticism
}

\section{Ayu Haswida Bt Abu Bakar}

To Link this Article: http://dx.doi.org/10.6007/IJARBSS/v10-i12/8353

DOI:10.6007/IJARBSS/v10-i12/8353

Received: 01 November 2020, Revised: 28 November 2020, Accepted: 13 December 2020

Published Online: 28 December 2020

In-Text Citation: (Abu Bakar, 2020).

To Cite this Article: Abu Bakar, A. H. B. (2020). Comedy Films of Malaysian Studio Era: A Social Culture Criticism. International Journal of Academic Research in Business and Social Sciences. 10(12), 537-545.

Copyright: @ 2020 The Author(s)

Published by Human Resource Management Academic Research Society (www.hrmars.com)

This article is published under the Creative Commons Attribution (CC BY 4.0) license. Anyone may reproduce, distribute, translate and create derivative works of this article (for both commercial and non-commercial purposes), subject to full attribution to the original publication and authors. The full terms of this license may be seen

at: http://creativecommons.org/licences/by/4.0/legalcode

Vol. 10, No. 12, 2020, Pg. 537 - 545

Full Terms \& Conditions of access and use can be found at http://hrmars.com/index.php/pages/detail/publication-ethics 


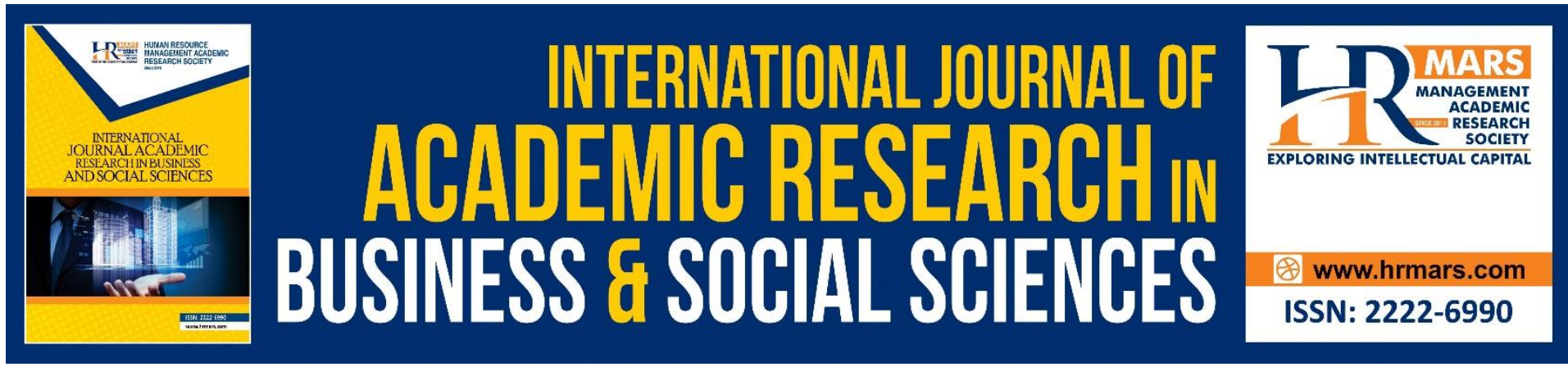

\title{
Comedy Films of Malaysian Studio Era: A Social Culture Criticism
}

\author{
Ayu Haswida Bt Abu Bakar \\ Faculty of film, theatre and animation, Universiti teknologi mara, malaysia \\ Email: ayuhaswida@gmail.com
}

\begin{abstract}
Comedy often is a serious matter because it is based on works with comments upon and critiques on social and political issues that have the potential of being presented as serious. Meanwhile the cinema is a very powerful cultural practice and institution. The focus of this research rests on comedy film as an agency of criticism to society. Thus, this research is to examine the capability of comedy cinema as a medium of criticism. The insight developed of this research constructed through a qualitative research design. Focuses on the Malaysian cinema era of studio. It rests on the framework of comedy as critiques on social culture that has the potential of being presented as serious. The objective of the study is to analysed these comedy films capable of functioning in a significant role as social criticism. Regard to the finding, it shows that comedy genre does to a degree which strongly influenced by socio-culture does serve as an 'agency' of meaning. Thus, critiques on social culture that has the potential of being presented as serious and is viewed as having the potential to criticise cultural discourses by underlining their status as fiction.
\end{abstract}

Keywords: Malaysian Cinema, Southeast Asian Cinema, Comedy Cinema, Singapore Studio Era, Cultural Criticism.

\section{Introduction}

Comedy defined by King (2002:2) as 'a work that is designed in some way to provoke laughter or humour on the part of the viewer'. Comedy cinema generates laughter through the comics and humours presentational mode, is in reality of most serious genre 'in the sense that it [comedy] reflected through the comic mode the deepest moral and social beliefs.' (Bazin, 1948; Bishop, 2014).

Comedy often is a serious matter because it is based on works with comments upon and critiques on social and political issues that have the potential of being presented as serious. For Bishop (2014), 'the comedy text, then, functions like a discursive glitch, or linguistic stammer in the smooth-running machine of the social and political order. Meanwhile the cinema is a very powerful cultural practice and institution.

\section{Problem Statement}

Books that draws on the issue of social cultural and political terrain of film comedy include Russell Ford's Why So Serious: On Philosophy and Comedy (2018), Cynthia Miller and A. 
Bowdoin Van Viper's The Laughing Dead: The Horror Comedy Film From Bride of Frankenstein to Zombieland (2016), Matthew Bevis's Comedy: A Short Introduction (2013), Lisa Trahair's The Philosophy of Comedy (2012), Micheal North's Machine -Age Comedy (2009), Steve Neal and Frank Krutnik's Popular Film and Television Comedy (2006), Steve Vineberg's High Comedy in American Film (2005), Frank Krutnik's Hollywood Comedian (2003) Christopher Beach's Class, Language and American Film Comedy (2002), King's Film Comedy, Dan Harrier's Film Parody (2000) and Andrew Hurton's Comedy/Cinema/Theory (1991).

The texts contribute greatly to the discussion of the potential of cultural and political critiques which regards to comedy and cinema. Thus, adds to the conversation of film comedy in two primary and inter-related ways. First, argues that for the centrality of comedy in film as a means for staging political and cultural criticism. Second, focuses on the cultural and political formation emerged from the cinema itself.

On this note, Malaysian comedy can be taken as the object of scrutiny in the matter of identifying class, gender, low and high culture through their story representation through the film narrative. 'Paying attention to the cultural forms enjoyed by a large number of people, cultural studies have suggested, also allows us to understand the way that 'common sense' comes to be formed, a common sense that enables ordinary people to be governed in ways that are often far from their own interest' (Matthews, 2000:2).

In this regard, the term 'common sense' connotes 'identity' conception by the collective understanding which Matthews refer as 'cultural form enjoyed by large number of people', that concerned of us and others. Therefore, 'comes to be formed', refers to the process of 'formulating' this identity, hence constructed a particular sense of 'national' a particular community by us and them.

To this certain extent, cultural studies offers two rationales for taking popular culture such as comedy films, seriously. Both, in the sense that, the films serve as an 'agency' of meaning, in regards of social and political. Also in the sense that, the films suggest the negotiation in the interests of the powerful, which refers to political apparatus.

Having said that, Malaysian comedy film genre is often subjected to critical neglect and is categorised as of low standard - as they are viewed as of inferior quality due to their subject matter by the print media.

Such being the case, this circumstances demonstrate a fundamental gap for this research. By this point, this research therefore argues that the Malaysian comedy genre is influenced by socio-political events and change. Thus, serves as a representational system of constructing and manifesting a particular Malay national identity to us and others.

On that note the focus of this research rests on comedy film as an agency of criticism to society. Thus, this research is to examine the capability of comedy cinema as a medium of criticism. The insight developed of this research constructed through a qualitative research design.

Focuses of this research rest on the framework of comedy as critiques on social culture that has the potential of presented as serious. The objective of the study is to analyse these comedy films capable of functioning in a significant role as social criticism. Regarding the finding, it showed that comedy film does to a degree which strongly influenced by socio-culture does serve as an 'agency' of meaning. Thus, critiques on social culture that has the potential of presented as serious and is viewed as having the potential to criticise cultural discourses by underlining their status as fiction.

Regard to the finding, it showed that comedy film does to a degree which strongly influenced by socio-culture does serve as an 'agency' of meaning. Thus, critiques on social 
culture that has the potential of presented as serious and is viewed as having the potential to criticise cultural discourses by underlining their status as fiction.

\section{Literature Review}

Comedy has a long history in Malaysian culture. It was prominent in oral folktale literature and drama long before the existence of cinemas in Malaysia. There was a strong oral and play tradition that functioned as entertainment but with underlying moral themes that served an educational function especially in the rural communities.

Today, the cinema becomes a dominant mode of communication in Malaysia and it plays a very significant role in conjuring up the imagined community of a nation. 'Cinema has the power and the obligation to represent the multiple and incompatible differences that are folded into the privileged and mono logical narrative of nationhood' (Dissanayake, 1994: xxvi).

Comedy films were the popular 'mode of presentation' in the studio era of the 70's90's and has remained so till today. Even so comedy films in Malaysia rarely win awards. Thus only three have won recognizable Best Comedy awards - at the Asian Film Festival; Pendekar Bujang Lapok (1959); Nujum Pak Belalang (1959) and Madu Tiga (1964), and two won the Best Film award at the Malaysian Film Festival; Kala Malam Bulan Mengambang (2008); Papadom (2009).

In the pre-cinema era Penglipur Lara, Tok Selampit, Awang Belanga and Awang Batil were 'professional' story-tellers who would travel from village to village to recite the traditional stories which were inherited from generation to generation. The method of delivering these stories varied, sometimes just narrating, or narrating in the form of song with or without the accompaniment of musical instruments. The 'non-professional' storytellers would come from senior family members such as the mother, father, grandmother or grandfather who would relate these stories to their young.

In addition there is the Mak Yong', a traditional Malay dance-drama and, 'the most elaborate of the dance-dramas and possibly the oldest' (Matusky and Chopyak in Miller and Williams, 2013:226), which flourished in the villages of Kelantan, a north-eastern state of Malaysia during the late $1800 \mathrm{~s}$. The major roles were mostly played by women, with men usually playing the two clown characters known as Peran; the comedian and the court jester.

Meanwhile the Wayang Kulitii, a type of a shadow puppet theatre which is 'an ancient form of traditional theatre in Malaysia,' (Matusky and Tan, 2017:14) represented stories drawn from the epics of Ramayana, and Mahabharata. The Malay version is The Story of King Rawana which introduced clown characters. According to Matusky and Tan (2017: 16), 'the two major clown characters, known as Pak Dogol and Wak Long, function as clown-servants to Rama.

These two characters have their origins in Malay culture from Kelantan and do not appear in the actual Ramayana. In other Malaysian states [...] these two clown characters are known by other names, but their physical resemblance is strikingly similar from one region to another. ${ }^{\text {iii }}$ For both Mak Yong and Wayang Kulit, it was their clown characters that held the audiences to their seats. Peran in Mak Yong and, Pak Dogol and Wak Long in Wayang Kulit structured the notion of the comedy in combination with other generic resources. For example, the Mak Yong reflected the characteristics of the drama genre while the Wayang Kulit highlighted the romances genre. 
To some degree, the Wayang Kulit, which is narrated by the tok dalang who is also known as the puppet master, fosters crude versions of cinema art-form and the filmviewing situation. The stage has a white cloth screen which functions like the cinema screen, and the tok dalang who sits behind the screen functions like a director who narrates the story using a third person or omniscient point of view, accompanied by the musicians, a lighting 'technician' and, of course, the puppets who are the actors. These images - the shadow puppet 'actors' playing themselves became 'stars' to the audiences.

The Peran characters; the comedian and court jester in Mak Yong, clown characters; Pak Dogol and Wak Long in Wayang Kulit, and the comical characters in humorous oral literature such as Mat Jenin, Si Luncai, Pak Kadok, Pak Pandir and Lebai Malang, made a particularly significant contribution to the development of humour and comedy in Malay[sian] society and culture. Thus, these comical elements in Mak Yong, Wayang Kulit and the oral literature celebrated and structured Malay popular culture. They served as a form of communication, artistic and aesthetic creation before the arrival of film 'culture', and fed into cinematic comedy.

Contrary to what is seen as a cinema that generates laughter through the comics and humours presentational mode, comedy is in reality of most serious genre 'in the sense that it [comedy] reflected through the comic mode the deepest moral and social beliefs.' (Bazin, 1948 in Bishop, 2014:1). Comedy often is a serious matter because it is based on works with comments upon and critiques all that has the potential of being presented as serious. For Bishop (2014:11), 'the comedy text, then, functions like a discursive glitch, or linguistic stammer in the smooth-running machine of the social order.'

Books that draws on the issue of social cultural and political terrain of film comedy include Russell Ford's Why So Serious: On Philosophy and Comedy (2018),Cynthia Miller and A. Bowdoin Van Viper's The Laughing Dead: The Horror Comedy Film From Bride of Frankenstein to Zombieland (2016), Matthew Bevis's Comedy: A Short Introduction (2013), Lisa Trahair's The Philosophy of Comedy (2012); Micheal North's Machine -Age Comedy (2009), Steve Neal and Frank Krutnik's Popular Film and Television Comedy (2006), Steve Vineberg's High Comedy in American Film (2005); Frank Krutnik's Hollywood Comedian (2003) Christopher Beach's Class, Language and American Film Comedy (2002), Geoff King's Film Comedy and Andrew Horton's Comedy/Cinema/Theory (1991).

The texts contribute greatly to the discussion of the potential of cultural and political critiques which regard to comedy and cinema. Thus, adds to the conversation of film comedy in two primary and inter-related ways. First, argues that, for the centrality of comedy in film as a means for staging political and cultural criticism. Second, focuses on the cultural and political formation emerged from the cinema itself.

\section{Research Design}

Research design focuses on qualitative research approaches. Centred on a case study method of Malaysian cinema comedy films of studio era in Singapore. For Creswell and Creswell (2017:297), qualitative methods 'rely on text and image data, have unique steps in data analysis, and draw on diverse design.' Thus, qualitative research method according to Creswell and Creswell is a holistic.

On this note, the holistic account needs what Creswell and Creswell (2017) mentioned deductive data analysis. Hence, the process of deductive data analysis as to construct and understand the holistic account serves as the mechanism of analysis through the process of interpretation for this study. 
The three selected films: Pendekar Bujang Lapuk (1959), Nujum Pak Belalang (1959) and Tiga (1964) of this era function as a research instrument. Measured through the film's narrative using a textual analysis method. These three films selected is justify giving the fact that they had been awarded The Best Comedy Film at Asian Film Festival in 1959, 1960 and 1964.

Data were sorted by the construction of social culture mocking conceptual defined through narrative variables: plot and characterisations.

\section{Discussion and Findings}

\section{The Studio Era}

Given the fact that both major studios, namely Malay Film Production and Cathay - Keris Organisation Limited, emerged in the era of British colonisation Malaysian comedy films produced in this era (see Table 1: Malaysian Comedy Films - Studio Era: 1940s -1977), fit Beach's (2002:9) notion of comedy that serves as a utopian form of escape or wishfulfilment for the locals that refers to Malay, as a response to the everyday and real situation of colonial Malaya.

\begin{tabular}{|l|l|l|l|}
\hline No & Title & No & Title \\
\hline $\mathbf{1}$ & Ahmad Albab & $\mathbf{1 6}$ & Masam-Masam Manis \\
\hline $\mathbf{2}$ & Ali Baba Bujang Lapuk & $\mathbf{1 7}$ & Mat Karung Guni \\
\hline $\mathbf{3}$ & Anak Bapak & $\mathbf{1 8}$ & Musang Berjanggut \\
\hline 4 & Bapa Saya & 19 & Nasib Do Re Mi \\
\hline $\mathbf{5}$ & Bujang lapok & $\mathbf{2 0}$ & Nasib Si Labu Labi \\
\hline 6 & Che Mamat Parang Tumpul & $\mathbf{2 1}$ & Nujum Pak Belalang \\
\hline $\mathbf{7}$ & Do Re Mi & $\mathbf{2 2}$ & Pak Pandir Moden \\
\hline $\mathbf{8}$ & Dua Kali Lima & $\mathbf{2 3}$ & Pendekar Bujang Lapok \\
\hline $\mathbf{9}$ & Kaki Kuda & $\mathbf{2 4}$ & Ragam P. Ramlee \\
\hline 10 & Keluarga 69 & 25 & Satay \\
\hline 11 & Keluarga Si Comot & 26 & Tiga Abdul \\
\hline 12 & Labu dan Labi & 27 & Tiga Botak \\
\hline 13 & Laksamana Do Re Mi & $\mathbf{2 8}$ & Seniman Bujang Lapok \\
\hline 14 & Mabuk Kepayang & 29 & Siti Muslihat \\
\hline 15 & Madu Tiga & 30 & Tukang Dukun \\
\hline
\end{tabular}

Table 1: Malaysian Comedy Films -Studio Era: 1940-1977

The films offered a utopian vision to them. These films offered a 'non-colonised' world; in a Malaya 'world' with its own culture, politics and adat, while also entertaining the audience through their humour and songs. These wish-fulfilment fantasies of liberation from the British coloniser, thus allowed the audiences to escape into utopian dreams of a 'colonial free' world. In effect, these films invented the Malay sense of hopes and dreams. This can be exemplified in the case of Pendekar Bujang Lapok (1959), which tells a story of three bachelors who seek a Silat Guru to learn from.

Set in a Malay rural area, the audience can identify this world as 'theirs'. The three bachelors are constructed as role-model of resistance, in the sense that they disobey and go against Ahmad Nisfu who represents the colonial power and is always in colonial attire: a white suit and a white hat. Pendekar Bujang Lapok portrays colonial oppression in a humorous manner, offering an opportunity to laugh at a very serious issue. 
It is important to note that films from the studio era were directed mainly by male directors, the most notable of whom was P. Ramlee. He was an established and distinguished director, actor, singer, songwriter and script writer who worked under Malay Film Production. To an extent, then, the studio era was synonymous with P. Ramlee and most of the successful comedy films in that era were directed and acted by him.

According to Hooker and Noraini (2003:154) 'without doubt it was the musical films starring, and subsequently also directed by, the Penang-born musician P. Ramlee that came mostly to be identified with "Malay culture" in the minds of the Malay movie-going public.' At the same time his films gained international recognition at Asian Film Festivals: Pendekar Bujang Lapok (1959) won The Best Comedy Film in the Sixth Asian Film Festival, 1959, Nujum Pak Belalang (1959) won The Best Comedy Film in the Seventh Asian Film Festival, 1960 and Tiga (1964) won The Best Comedy Film in the Eleventh Asian Film Festival, 1964.

The films constructed a mode of male prioritisation with the point of view, romance and concerns seen from a male perspective together with a dominant and positive Malay male father-figure image underlying the 'typical' ideals of domestic family life that secure the patriarchal system.

For example, Tiga (1964) tells the story of Jamil, a middle-class man, who runs his father-in-law's company. With the approval of his father-in-law, he secretly marries another two beautiful women without his first wife's knowledge. In order that his secret is kept safe, all his three wives are kept in the dark about each other with the help of his assistant and his father-in-law. To them, he is a good husband that has only one wife. His bluff is accidentally exposed when his three wives become friends. But, ironically, the film has a happy ending in which he lives happily with his three wives and with loving and supportive in-laws.

Some comedy films in the studio era did function to some degree as social critiques of Malay class differences and expressed a desire to close the gap between the classes. They served as a humorous assault on the peculiarities of social status. Nujum Pak Belalang (1959), for example, tells a story of a Malay lazy peasant, Pak Belalang, who has a young, smart and hard-working son.

Pak Belalang becomes well known and is recognised as a great fortune-teller after his son steals the villagers' cows and goats and later spreads the news that his father is a fortune-teller. It is actually the son idea to steal the animals and hide them. He then spreads the news saying that his father is a fortune teller while the whole villagers are looking for the lost animals. After a series of steals and hides done by the son, and later fortune-telling by the father, Pak Belalang become a famous fortune-teller in his village. One day, the Sultan loses his treasure and the village head suggests Pak Belalang to the Sultan, not knowing that he is actually a fake fortune-teller. But as luck is always on his side, he manages to tell the Sultan where the hidden treasure is.

The story ends happily with him being appointed as the country's fortune-teller and marrying the Sultan's daughter. Nujum Pak Belalang thus repeats the story of how the lazy proletarian is capable of outsmarting and fooling the bourgeois community, so elevating himself to a better position. As the Sultan has no heir, marrying the Sultan's only daughter makes him next in line to the throne.

\section{Conclusion}

Films of this era then, can be considered as 'Malay male comedic' narratives which subject women to the male gaze and present them as subordinate. Thus, the Malay identities 
constructed through these films also had a powerful influence on the way Malay perceived their place within the framework of British colonisation. Which to an extend the Malay represented signified with the characteristics of lazy and manipulative for the male. Fragile and slightly stupid or easily manipulated by the male. Having said that, these films function as escapist fantasies and illustrated a sense of hope of a Malay world of their own.

\section{Refferences}

Beach, C. (2002), Class, Language, and American Film Comedy, Cambridge: Cambridge University Press.

Bevis, M. (2013), Comedy: A Short Introduction, Oxford Press: UK

Bishop, K. (2010), American Zombie Gothic: The Rise and Fall (And Rise) of The Walking Dead in Popular Culture, USA: McFarland \& Company, Inc., Publishers.

Bishop, R. (2014), Comedy Cultural Critique in American Film, UK: Edinburgh University Press.

Creswell, J., \& Creswell, J. (2017), Research Design: Qualitative, Quantitative, Mixed Methods Approaches, USA: Sage Publication.

Dissanayake, W. (1994), Colonialism and Nationalism in Asian Cinema: Indiana University Press.

Ford, R. (2018), Why So Serious: On Philosophy and Comedy, Routledge: UK

Hooker, V., \& Othman, N. (2003), Malaysia: Islam, Society and Politics, Singapore: Institute of Southeast Asian Studies.

Horton, A. (1991), Comedy/Cinema/Theory, London: University of California Press Ltd

King, G. (2002), Film Comedy. USA: Wallflower Press.

Krutnik, F. (2003), Hollywoods Comedians: The Film Reader, London: Routledge.

Matusky, P., \& Chopyak, J. (2013), Peninsular Malaysia in Miller, T \& Willaims, S., The Garland Encyclopedia of World Music: Southeast Asia, USA: Routledge.

Matusky, P., \& Beng, T. S. (2017), The Music of Malaysia: The Classical Folk and Syncretic Traditions, United Kingdom: Routledge.

Miller, C., \& Van Viper, A. (2016), The Laughing Dead: The Horror Comedy Film from Bride of Frankenstein to Zombieland, USA: Rowman \& Littlefield.

Mughal, H. A. (2019). Support at Work and its Relationship with Employee Performance: Critical Insights for Early Scholars. Annals of Contemporary Developments in Management \& HR (ACDMHR), 1(3), 16-21.

Neale, S., \& Krutnik, F. (2016), Popular Film and Television Comedy, UK: Routledge.

North, M. (2009), Machine-Age Comedy, UK: Oxford University.

Trahair, L. (2012), The Philosophy of Comedy: Sense and Nonsense in Early Cinematic Slapstick, USA: State University of New York Press.

Vinerberg, S. (2005), High Comedy American Film: Class \& Humor from the 1920s to the Present, UK: Rowman \& Littlefield.

\section{Appendices}

\footnotetext{
' Mak Yong is 'performed mostly by women, also the name of the leading female role within this form' (Osnes, 2001:205). Mak Yong 'is thought to be the creation of female attached to the Malay court of Patani, Southern Thailand [...]. Performances last a few nights, from sundown till the early morning hours. Mak Yong serves as a healing ritual. The role of the lead, Mak Yong is that of an entertainer and spirit medium. (Osnes, 2001:205)
} 
ii Wayang Kulit stories recited by a puppet master; Tok Dalang 'who manipulates the puppets in shadows projected on a screen. In this very old form of theatre a small ensemble plays the music to accompany the movement of the puppets and the events in the stories.' (Matusky \& Tan, 2004:16)

iii There are four types of Wayang Kulit in Malaysia. 'Each with a specific name and distinctive style. These are the wayang kulit Jawa (also called the wayang kulit purwa; the Javanese shadow puppet play), the wayang kulit gedek (or simply wayang gedek; a mixture of Thai and Malay folk styles of shadow puppet play), the wayang kulit Melayu (also called wayang Jawa; the Malay court form of shadow puppet play) and the wayang kulit Kelantan (also called the wayang kulit Siam; the Kelantanese folk shadow puppet play)' (Matusky \& Tan, 2004:16).

$* *$ Note

This article is taken from my PhD thesis (2020):

Malayness as Culture Political Criticism: A Close Textual Analysis of Comedy Films (2006-2010) 